\section{The discovery of Trypanosoma cruzi and Chagas disease (1908-1909): tropical medicine in Brazil ${ }^{1}$}

\section{A descoberta do Trypanosoma cruzi e da doença de Chagas (1908-1909): medicina tropical no Brasil}

Simone Petraglia Kropf

\author{
Researcher at Casa de Oswaldo Cruz/Fundação Oswaldo Cruz \\ Avenida Brasil, 4036/400 \\ 21040-361 - Rio de Janeiro - RJ - Brasil \\ simonek@coc.fiocruz.br \\ Magali Romero Sá \\ Researcher at Casa de Oswaldo Cruz/Fundação Oswaldo Cruz \\ magali@coc.fiocruz.br \\ Fundação Oswaldo Cruz, Casa de Oswaldo Cruz \\ Avenida Brasil, 4036/400 \\ 21040-361 - Rio de Janeiro - RJ - Brasil \\ Translation: Derrick Phillips \\ Submitted on December 2008 \\ Approved on March 2009.
}

KROPF, Simone Petraglia; SÁ, Magali Romero. The discovery of Trypanosoma cruzi and Chagas disease (1908-1909): tropical medicine in Brazil. História, Ciências, Saúde - Manguinhos. Rio de Janeiro, v.16, supl. 1, jul. 2009, p.13-34.

\section{Abstract}

This article analyzes the discovery of Chagas disease and the parasite that causes it (Trypanosoma cruzi) by Carlos Chagas in 1908/1909, with a special focus on the scientific and social context in which this occurred. Its inclusion in the international debate on European tropical medicine especially with researchers from the German school of protozoology - and its connection with discussions on the modernization of the recently established Brazilian Republic are also examined. The discovery of Chagas disease became a decisive aspect in the scientific project that Oswaldo Cruz sought to establish at the institute that bears his name. It was extolled as a symbol of Brazil's scientific ability to produce knowledge in line with the international scientific agenda, while simultaneously being attuned to the specific problems of the country.

Keywords: Chagas disease; Trypanosoma cruzi; tropical medicine; Brazil; Germany.

\section{Resumo}

Analisa o contexto científico e social da descoberta, por Carlos Chagas, em 1908/ 1909, da doença que leva seu nome, bem como do Trypanosoma cruzi, parasito que causa esta enfermidade. Examina sua inserção no debate internacional da medicina tropical - especialmente com pesquisadores da escola alemã de protozoologia - e nas discussões sobre a modernização brasileira. A descoberta foi decisiva ao projeto de ciência que Oswaldo Cruz pretendida erigir no Instituto de Manguinhos. Foi enaltecida como símbolo da capacidade da ciência nacional em produzir conhecimentos afinados com a agenda científica internacional e, ao mesmo tempo, relacionados aos problemas específicos do Brasil.

Palavras-chave: doença de Chagas; Trypanosoma cruzi; medicina tropical; Brasil; Alemanha. 
$\mathrm{O}$ n April 15, 1909, Carlos Chagas (1878-1934), a young researcher at Instituto Oswaldo Cruz (IOC; Oswaldo Cruz Institute), announced to the scientific world the discovery in Lassance, state of Minas Gerais, of a new tropical disease caused by the protozoan Trypanosoma cruzi (also described by him in 1908) and transmitted by a hematophagous bug popularly known as 'barbeiro' (known in english as barber bug or kissing bug) that proliferated in the mud walls of typical houses of the poor in rural areas (Chagas, 1909c). The 'triple discovery' (vector, pathogen and human disease) - communicated by Oswaldo Cruz to the prestigious Academia Nacional de Medicina (ANM; National Academy of Medicine) on April 22 (Chagas, 1909e) - was celebrated as 'a great breakthrough' in Brazilian science and one of the 'triumphs' of the newly-created Instituto Soroterápico Federal (Federal Serum Therapy Institute), renamed as Instituto Oswaldo Cruz in 1908. ${ }^{2}$

The study of the new trypanosome addressed important aspects of the intricate biological questions concerning the host-parasite relationship, which were challenging the international scientific community (Sá, 2005). The new disease, moreover, generated intense debate on health and life conditions in rural areas of the country. According to Chagas, since it caused permanent damage to the physical and mental development of children and young people, American trypanosomiasis seriously jeopardized the vitality of the people of the hinterlands and, consequently, the 'progress' of Brazil (Kropf, 2009).

The scope of this paper is to analyze the process that led to the description of $T$. cruzi and Chagas disease, and the significance that these discoveries had on the social institutionalization and legitimation of science in Brazil in the first decades of the twentieth century, as well as its links with international science and the specific issues in the Brazilian context. Occurring at a time of dissemination of Mansonian tropical medicine (Arnold, 1996; Worboys, 1997) ${ }^{3}$ when institutions involved in this field (like the Instituto Oswaldo Cruz) were created in Brazil (Stepan, 1976; Benchimol, Teixeira, 1993; Benchimol, Sá, 2005, 2006), this episode soon assumed far greater relevance than the scientific achievement of one individual. The discovery became a symbolically significant event that represented the scientific project that Oswaldo Cruz sought to establish at Instituto de Manguinhos. In addition to making an original contribution to knowledge produced at that time on the relationship between vectors, parasites and human diseases, it was acclaimed as a symbol of Brazilian scientific capability. It also highlighted the possibility of associating the production of knowledge in line with the international agenda with a commitment to provide solutions to sanitary problems of the country, thereby paving the way for its modernization.

It is thus an exemplary episode for reflection on tropical medicine in Brazil and in broader terms about the processes of circulation and exchange between different scientific groups and institutions. In addition to the studies that emphasize the local dimension of scientific activity and its close relations with society, this is yet another case that shows how Brazilian scientists had recourse to concepts and theories developed in foreign scientific centers, not in a passive or mimetic manner, but as active subjects of their production and validation at an international level. 


\section{Discovery in the hinterlands of Minas}

Carlos Chagas was born in 1878 on a coffee farm near the small town of Oliveira in the state of Minas Gerais. He moved to Rio de Janeiro - which was the federal capital at that time - in 1897. He graduated from the Faculdade de Medicina (Faculty of Medicine) in that city, with a thesis on malaria (1903), conducted at what was then known as the Instituto Soroterápico Federal, under the direction of Oswaldo Cruz. In June 1907, Chagas was sent to the north of the state of Minas Gerais to implement a campaign against malaria, which was jeopardizing the extension works on the Central do Brasil Railroad between Corinto and Pirapora. ${ }^{4}$ The railroad was inaugurated during the Imperial times as an important means of integration and settlement of the national territory and was the main form of transport for Brazilian agricultural production for export. The original plan was to extend it from the federal capital to the northernmost city of Belém do Pará. ${ }^{5}$

In the small settlement of São Gonçalo das Tabocas (renamed Lassance, in honor of engineer Ernesto Lassance Cunha, with the inauguration of the railway station in February 1908), Chagas installed a small laboratory in a railway wagon, which he also used as a dormitory. While coordinating the prophylactic campaign he collected and examined species of Brazilian fauna, motivated by his growing interest in entomology and protozoology, which were areas of special relevance in the research agenda of Instituto de Manguinhos (Benchimol, Sá, 2005, 2006). In 1908, while examining the blood of a marmoset (Callithrix penicillata), he identified a protozoan of the Trypanosoma genus that he named Trypanosoma minasense (Chagas, 1908). The new species was not pathogenic for the monkey. At the time, the study of trypanosomes was on the agenda of European tropical medicine, ever since it was proven that it caused several animal diseases (such as surra and nagana) ${ }^{6}$ and also a human disease called African trypanosomiasis, considered a serious obstacle to the occupation of various regions in that continent. ${ }^{7}$

In addition to investigating parasites, Chagas was interested in insects that might act as vectors for them. He heard about a hematophagous insect that proliferated in the wattle and daub huts in the region from engineer Cornélio Homem Cantarino Mota. It was popularly known as 'barbeiro' since it tends to bite peoples' faces while sleeping. Aware of the importance of bloodsuckers - such as mosquitoes - as transmitters of parasitic diseases, Chagas examined some bugs and found flagellate protozoan forms in their intestines that could be a natural parasite of the bug or else a trypanosome in vertebrates. In this case, it could even be an evolutionary stage of $T$. minasense.

Since he did not have the laboratory facilities in Lassance to elucidate the matter, he sent a few insects to Manguinhos. Oswaldo Cruz put them in contact with marmosets bred in the laboratory - therefore free of infection - and then informed Chagas that he had found forms of trypanosomes in the blood of one of the animals, which had been taken ill. Chagas returned to the Institute and found that the protozoan was not T. minasense. It was indeed a new species, which he named Trypanosoma cruzi, in honor of his 'master' Oswaldo Cruz. In December 1908, he submitted the work for publication in the journal of the Institut für Schiffs- und Tropenkrankheiten (Institute for Maritime and Tropical Diseases) in Hamburg, Germany, announcing the discovery of the two trypanosomes (Chagas, 1909a). ${ }^{8}$ 
At the IOC, Chagas began to conduct systematic studies into the life cycle of $T$. cruzi. In search of other vertebrate hosts of the parasite, and suspecting that humans could be one of them, he returned to Lassance where he carried out systematic tests on residents. When recounting the episode, he said:

\begin{abstract}
We concentrated on our central idea of the notion of human dwellings as being the preferred, and possibly exclusive, habitat of the hematophagous bug, as well as the well known fact that human blood is its means of sustenance par excellence. It was therefore reasonable to consider the possibility of an-infectious condition in the home in which the vertebrate host of the parasite might be a domestic animal or even humans themselves (Chagas, 1910b, p.423). ${ }^{9}$
\end{abstract}

After finding T. cruzi in the blood of a cat, which indicated the existence of a domestic host, he identified the parasite in the blood of a feverish child on April 14, 1909. In a preliminary note sent to Brazil-Medico, he announced the discovery that would seal his reputation:

We found trypanosomes, the morphology of which is identical to Trypanosoma cruzi in a feverish, deeply anemic and bruised patient with swollen ganglial pleiads. In the absence of any other etiology for the morbid symptoms observed, and in line with previous experiments in animals, we believe it is a human trypanosomiasis, a disease caused by Trypanosoma cruzi, which is transmitted by Conorhinus sanguissuga (?) (Chagas, 1909c, p.161). ${ }^{10}$

Berenice, a two-year-old girl, was the first case of what would henceforth be considered a new human disease. ${ }^{11}$ The fact was also immediately disseminated to the international scientific community, in the Archiv für Schiffs- und Tropen-Hygiene (Chagas, 1909f) and the Bulletin de la Société de Pathologie Exotique journals (Chagas, 1909b).

Chagas achieved great renown in the Brazilian medical community, and on October 26, 1910 he became a member of the Academia Nacional de Medicina. He presented his research on the new trypanosomiasis (Chagas, 1910b) which, at the suggestion of the professor of the Faculdade de Medicina do Rio de Janeirro, Miguel Couto, came to be known as Chagas disease. The discovery was also acknowledged abroad. In 1911, at the Brazilian pavilion of the International Exposition of Hygiene and Demography, staged in Dresden, Germany, Chagas disease was the scope of intense public interest. In 1912, the Brazilian researcher was awarded the Schaudinn Prize for protozoology by the Institute of Maritime and Tropical Diseases in Hamburg. In 1913, he was nominated for the Nobel Prize for Medicine. ${ }^{12}$

Under the leadership of Chagas, and with the collaboration of several researchers, the new trypanosomiasis became the showcase for the program of studies at the IOC: investigations were initiated at the IOC on the biological characteristics of the vector, of the parasite and its carriers; the clinical picture and pathogenesis of the infection; the epidemiological characteristics; the transmission mechanisms and diagnosis techniques (Benchimol, Teixeira, 1993; Perleth, 1997; Coutinho, 1999; Kropf, Azevedo, Ferreira, 2003; Delaporte, 2003; Kropf, 2009). 


\section{Protozoology at Manguinhos and cooperation with the Germans}

Historians have stressed the importance of the discovery of Chagas disease for the institutionalization of European tropical medicine and especially for the consolidation of protozoology as a decisive area for the recognition of the IOC as a center for research into tropical diseases (Stepan, 1976; Benchimol, Teixeira, 1993; Perleth, 1997; Worboys, 1997; Coutinho, 1999; Delaporte, 2003; Sá, 2005; Kropf, 2009). The discovery of T. cruzi and the study of the new parasite - the first aspect to which Chagas devoted himself systematically even before identifying the human infection and embarking on clinical study of the new disease - were an example of the inclusion of Manguinhos in the field of tropical medicine and were to a great extent the result of research conducted at Manguinhos in collaboration with German researchers.

Despite having been created with a specific objective - namely the production of serum and vaccine for bubonic plague, which threatened the Brazilian capital - the Instituto Oswaldo Cruz rapidly acquired an international reputation. Manson and Pasteur's joint traditions of bacteriology, parasitology and medical entomology became the main areas of research of the new institution. ${ }^{13}$ During its first seven years of existence, a couple of relevant contributions had already been made, such as the discovery of the life cycle of Halteridium in pigeons, by Henrique Aragão, the development of a new technique for preparation of vaccine against the symptomatic carbuncle by Alcides Godoy, and the identification and description of new insect vectors of diseases, especially malaria, conducted by Oswaldo Cruz, Adolpho Lutz, Arthur Neiva and by Carlos Chagas himself (Benchimol, Teixeira, 1993; Benchimol, Sá, 2005, 2006).

The association with German researchers was crucial for the development of research on these topics that were on the agenda of international medical science. When Chagas was about to describe the two new trypanosomes found in Minas Gerais, two German scientists arrived at Manguinhos, invited by Oswaldo Cruz to spend six months conducting research. They were the protozoologist Stanislaus von Prowazek Edler von Lanow (1875-1915) and the pharmacist Gustav Giemsa (1867-1948). Ten months later another German protozoologist, Max Hartmann, also arrived at the institution. The influence of German protozoology on Chagas' work were noted and widely discussed by Delaporte (2003). Perleth (1997) also calls attention to the influence of Fritz Schaudinn's school in the episode of the discovery of Chagas disease. ${ }^{14}$ This is a view, however, which is not fully supported by Coutinho and Dias (1999, p.20), who state: "The influence of German researchers M. Hartmann and S. Prowazek is unquestionably important. However, the chronology of the discovery does not support an earlier link with the Schaudinn school". In our view, this influence was considerable and cannot be disregarded, since from the very beginning Prowazek, and later Hartmann, were in close contact with Chagas, exchanging information and corroborating findings (Sá, 2005).

Prowazek and Giemsa arrived in Rio de Janeiro on July 3, 1908, from the Institut für Schiffs- und Tropenkrankheiten. Prowazek had a solid background and extensive knowledge about cellular physiology, as well as experience in studies with trypanosomes. He came to IOC with the commitment to teach courses in Protozoology and publish the results of his 
research in the journal Memórias do Instituto Oswaldo Cruz. ${ }^{15}$ Giemsa had the assignment of teaching Chemistry and publishing his research in the same institutional journal. ${ }^{16}$

The Institut für Schiffs- und Tropenkrankheiten was founded at about the same time as Manguinhos, but the motive behind their creation was not the same. Although the Hamburg Institute had philosophical affinities with the Brazilian research center, the factors behind the former's creation were nearly the same as those behind the founding of the Liverpool School of Tropical Medicine, in England. ${ }^{17}$ Since the seaports of Liverpool and Hamburg were gateways for several tropical diseases, the two institutions had the purpose of conducting studies on tropical diseases and assisting these and other ports in matters regarding health problems arising from extensive trade with tropical countries. Other aims of the Hamburg Institute were to train physicians for service in the tropics, the treatment of patients afflicted with tropical diseases (malaria in particular), and the study of tropical hygiene (Kraus, 1998, p.14).

When Prowazek was invited by Oswaldo Cruz, he was head of the Protozoan Laboratory at the Hamburg Institute. Having graduated in medicine in 1899, Prowazek showed an early interest in cellular physiology, publishing more than 25 works between his graduation and the time he started working with Fritz Schaudinn, in 1903. The two researchers then studied protist evolution, an effort which led Schaudinn to publish, in 1904, an important work on the life cycle of Trypanosoma noctua (a bird parasite), describing its sexual cycle. Prowazek worked on yet another Trypanosoma (T. lewisi). His article, which came out the following year (Prowazek, 1905), included not only information on the sexual cycle of the parasite, but also emphatic comments on the alternation of generations between trypanosomes and endoglobulate Haematozoans. ${ }^{18}$ In the summer of 1905, Prowazek moved to the Imperial Department of Public Health in Berlin in order to replace Schaudinn in the Protozoan Laboratory. Schaudinn had been transferred to the Institut für Schiffs- und Tropenkrankheiten, in Hamburg, to set up a similar laboratory there. After his premature death in the summer of 1906 (Schaudinn was only 35 years old), Prowazek replaced him in Hamburg (Kraus, 1998, p.152-154).

At the same time, Brazilian researchers were following closely the research conducted by the British, French and Germans in protozoology. Their main goal was to search for parasites in species of the Brazilian fauna, and try to establish links between parasites and vectors. Following the important work by Aragão on pigeon Halteridium, which came out in 1907, revealing important aspects of the life cycle of the plasmodium of malaria in birds, in the same year Lutz published an extensive work on different species of bird Haemosporidia, found in nine bird orders. He also studied the role of Lynchia (a fly) as a vector. On his work on horse trypanosomiasis, Lutz provides interesting information regarding the circulation of scientific material among Brazilian and foreign researchers. ${ }^{19}$ He said: “... the Elmassien virus [trypanosome] was taken to Europe and used by Laveran and Mesnil in Paris for the study of the parasite and the disease .... From there, the virus went to several laboratories and I had the opportunity to study it here, as well as the trypanosomes of surra and nagana" (Lutz, 1908, p.37). ${ }^{20}$ Lutz transferred from Instituto Bacteriológico de São Paulo (Bacteriological Institute of São Paulo) to Instituto Oswaldo 
Cruz in 1908, making further contributions during this most productive era, especially through his works on medical zoology. ${ }^{21}$

Prowazek brought to Instituto Oswaldo Cruz some animals infected with dourine, a disease caused by Trypanosoma equiperdum, which occurs in horses and is only transmitted during coitus, as reported by Henrique Aragão to Adolpho Lutz on July 4, 1908. ${ }^{22}$ At the time, Aragão also sent specimens of Lynchia contaminated with Halteridium to Lutz. Prowazek also contributed some interesting news from Hamburg about research on trypanosomes: the following number of the Archiv für Schiffs- und Tropen-Hygiene was to include a note on a trypanosome found in a Brazilian monkey. The discovery was made by Herbert von Berenberg-Gossler while searching for malaria parasites in the blood of a bald-uakari monkey (the 'cacajao' Brachyurus calvus) from the Brazilian Amazon. ${ }^{23}$ Prior to these, the only trypanosomes from monkeys recorded in scientific literature were those from a chimpanzee in the French Congo (Africa) mentioned in a brief note by the German marine-officer, Hans Ziemann, in 1902.

The discovery of the Amazonian trypanosome was published by Berenberg-Gossler in 1908. In the article, he gave a brief description of the parasite and suggested a possible affinity of the new trypanosome with Trypanosoma gambiense (the agent of human trypanosomiasis in Africa). He also suggested that the former could be a new species, but did not name it. The article is dated July 1908 (Berenberg-Gossler, 1908)

Shortly thereafter, in a work co-authored with Richard Gonder, this new trypanosome was named in homage of Prowazek (Trypanosoma prowazeki). In this article, the authors mention that Prowazek had informed them by letter that he had discovered a new species of trypanosome in monkeys in Brazil (Gonder, Berenberg-Gossler, 1908, p.53). ${ }^{24}$ It seems, however, that Prowazek was referring to the new species discovered by Chagas in a marmoset monkey. After analysis of the facts, it becomes clear that, at the time, Chagas was just beginning his experiments on the chritidian forms of the parasite found in the 'barbeiro' bugs, which would later be identified by him as a new trypanosome, the T. cruzi. ${ }^{25}$

The unjustified credit given to Prowazek by Berenberg-Gossler for the discovery of the new monkey trypanosome in Brazil obliged him to go public to rectify the error. In a joint note with Chagas in the same Malaria journal dated February 1909, it is stated: "In relation to this I would like to inform that two new species of trypanosomes [T. minasense and $T$. cruzi] were first discovered and thoroughly examined by Dr. C. Chagas in Hapale penicillate (Latin). One of the trypanosomes closely resembles the intracellular haemosporidia in terms of schizogony and temporary intracellular life, even though it does not manifest mobile states of reproduction" (Chagas, Prowazek, 1909, p.138).

At the time that the above note was released, Chagas also contributed an article to the journal of the Institut für Schiffs- und Tropenkrankheiten regarding the work - concluded on December 17, 1908 - about his two new trypanosomes (Chagas, 1909a). The description of the T. minasense had already been released in Brazil-Medico in December, 1908 (Chagas, 1908). In the description of T. cruzi, which he considered the most interesting since it had a life cycle of 'great interest', Chagas stresses that his studies on this subject had been developed "under the supervision of Dr. Prowazek" (Chagas, 1909a, p.122). The tribute 
paid by Chagas to the German protozoologist acknowledges him as being the expert behind the process that led to his new findings.

The description by Chagas of the T. cruzi cycle inside the bug showed peculiarities that caught the attention of Prowazek. In Chagas' words:

\begin{abstract}
The study of the development of the parasites in the intestinal tract of the Conorhinus revealed very interesting facts: 6 to 8 hours after the blood was taken, trypanosomes without undulating membranes and cilia may be found in the stomach of the bugs. Sometime later, the migration of the blepharoplast to the free extremity near the nucleus is observed, followed by a more rounded body form and intense multiplication. Besides, sexual reproduction seems to occur in the stomach of the Conorhinus that is indicated by the location of the corpuscles, which manifest characteristics of cysts. At the end of the intestinal tract, numerous forms of crithidia are found, among which we can observe many forms still in development. In the Conorhinus coelom, I found adult forms of parasites that were distinct from those found in the intestinal tract as they bore characteristics of adult trypanosomes (Chagas, 1909a, p.122). ${ }^{26}$
\end{abstract}

Prowazek returned to Hamburg on February 10, 1909. ${ }^{27}$ Some months later he published "Critical observations on trypanosome problems" in the Archiv für Schiffs- und TropenHygiene (Prowazek, 1909). The German protozoologist analyzed the concept of the genus Trypanosoma and other Trypanosomatidae, and initiated a discussion on the development of trypanosomes in intermediate hosts. Chagas' work on T. cruzi, published a short time before in Germany (Chagas, 1910a), was also cited by Prowazek to explain the morphological alterations of the Trypanosoma genus. The German scientist stressed that the most important aspect in Chagas' observations were the adult forms of parasites found in the Conorhinus coelom, different from those of the intestinal tract since they presented characteristics of adult trypanosomes. For Prowazek, these facts, obtained partly on an experimental basis by researchers like Paul Manteufel, Friedrich Kleine, F.S.H. Baldrey and C. Chagas, favored the concept of the development of trypanosomes in intermediate hosts (Prowazek, 1909). The insect was indeed not just a mechanical transmitter of the parasite but also an intermediate host - this was the crux of the matter. ${ }^{28}$

Prowazek also emphasized that: "Regarding pathogenic trypanosomes, the development in an intermediary host is not definitively proven. Nevertheless, evidence has been accumulating in this respect over the past few years, and it is to be expected that in the years to come the final answer to the problem will be found" (Prowazek, 1909, p.307-308).

The evidence Prowazek was referring to was published by the German researcher, Friedrich Kleine, who travelled to Africa as a member of the $1^{\text {st }}$ German East Africa Sleeping Sickness Commission in 1906-7. In March 1909, Kleine described the development of Trypanosoma gambiense in tsetse flies, namely the agent of African human trypanosomiasis (Kleine, 1909). He carried out transmission experiments from human patients to apes and monkeys, proving that the parasite had to be present in tsetse flies for a minimum period before it could cause infection. He subsequently showed that only the metacyclic forms in the salivary glands of the insect were infectious. ${ }^{29}$

Despite Kleine's thesis, at the time it was believed that the transmission of T. gambiense by the Glossinia fly was simply mechanical, a concept sustained by David Bruce and supported by some contemporary researchers (Scott, 1942, p.462). It was only after the 
confirmation of Kleine's work by Bruce in 1911, and the disclosure of the parasite's full cycle by Muriel Robertson in 1913, that Glossinia became fully recognized as the intermediary vector of T. gambiense (Busvine, 1993, p.43-44).

It was within the scope of this debate on the nature of the relationship between trypanosomes and their hosts that one of Chagas' most important contributions to the field of tropical medicine is to be found, namely the study of the 'barbeiro' bug as the intermediary host of $T$. cruzi.

The account of Chagas' discovery of a new human trypanosomiasis in the New World immediately reached Germany, as Chagas had once again submitted his latest findings to the Archiv für Schiffs- und TropenHygiene on April 15, 1909 (Chagas, 1909f) Subsequently, Chagas embarked on a series of experiments on the Callithrix penicilatta monkey infected with human blood bearing trypanosomes. He also examined parasites in bugs that had been both naturally and experimentally infected. In this manner, he was able to describe the different cycles of the T. cruzi, both in the vertebrate host and in the invertebrate vector. Chagas also attempted to demonstrate that there was a biological relationship between parasite and vector, rather than a mechanical transfer of parasites. The results of such findings came out in Memórias do Instituto Oswaldo Cruz in August 1909 (Chagas, 1909d). In this study - which is still the most often quoted in literature on American trypanosomiasis - Chagas gives a thorough description of T. cruzi and the peculiar characteristics of its evolution. The Brazilian scientist officially declares his affinity with the school of protozoology espoused by Schaudinn and his followers (Chagas, 1909d).

According to Chagas, the main aspect of this affinity was the contribution that the study of the new parasite brought to the discussion on the classification of protozoa. At the time, he counted on the scientific support of the German researcher Max Hartmann, a well-known protozoologist from the Berlin Institut für Infektionskrankheiten (Infectious Disease Institute of Berlin). ${ }^{30}$ When he found what he considered to be multiple division (schizogony) of the parasite in the lung tissue of experimentally infected animals, Chagas established a substantial difference in relation to previously known trypanosomes, the multiplication of which occurs by binary division ${ }^{31}$. He therefore decided that a new genus (Schizotrypanum) needed to be created to classify this species and he proceeded to call it Schizotrypanum cruzi. In addition to schizogony, according to Chagas, other features confirmed Schaudinn's theory on the close similarity between haemosporidia and trypanosomes (protozoa that reproduce inside blood cells, among which those of malaria). Until then they were considered independent and well-defined groups. The discovery of $T$. cruzi would therefore give substance to Hartmann's proposal that haemosporidia and trypanosomes should be grouped together under the new order of Binucleata (Chagas, 1909d). ${ }^{32}$

However, the most important aspect of Chagas' contribution to the international debate on tropical medicine concerned the role of haematophagous insects in the transmission of trypanosomes of vertebrates (Sá, 2005). Chagas endorsed Kleine's view, shared by Schaudinn, Prowazek and other scientists, that the transmission of the trypanosome was not made in a mechanical manner, but depended on a fundamental biological relationship between parasite and vector, according to the model established by Manson. ${ }^{33}$ Investigation 
by Carlos Chagas on the evolution of $S$. cruzi in the organism of the 'barbeiro' bug were of interest to the "issues of doctrine concerning the mechanism of transmission of haemoflagellates by invertebrates" and, despite some as yet unclear points, it elucidated "many hitherto obscure phenomena, regarding the role of intermediary hosts in trypanosomiasis" (Chagas, 1909d, p.181). Chagas came to the following conclusion (p.213): "The exclusive mechanical role of the hemipterus [insect] is therefore excluded, and even if the latter can serve as a mere vehicle for the immediate transmission of the parasite, which we have never verified, the main function will be that of intermediary host, in which the flagellate goes through its life cycle ....".34

The Brazilian scientist thus assumed an active role in finding solutions to the 'conundrums' of European tropical medicine. The dialogue with the German researchers was decisive both in providing theoretical references for his research, and in legitimating his own contribution in the field. However, the impact of Chagas' work was not restricted to this scientific area, as the description of the new trypanosomiasis generated intense debate on the social dimension of the disease, and consequently on the social dimension of tropical medicine in Brazil.

\section{The discovery of the 'disease of Brazil'}

According to Augustine Brannigan (1984), scientists and lay people traditionally consider 'discoveries' the very essence of scientific activity. This is particularly true from the seventeenth century onwards, when it came to include the responsibility for solving 'mysteries' and 'enigmas' of nature that were seen as a kind of 'reality' governed by laws and structures that were inaccessible to the common man. The term itself denotes the prior existence of latent phenomena, waiting to be 'revealed' by trained and rational minds. Seeking to 'demystify' the scientific discovery, according to a history and a sociology of science in line with the formulations of Thomas Kuhn, Brannigan emphasizes that discoveries occur under certain conditions and social contexts, and their status per se is the result of a socially determined process. For a discovery to be recognized as such, it presupposes complex negotiations between different social actors. Thus, treating a discovery critically involves understanding how and why a given scientific achievement has been recognized and sanctioned as such. ${ }^{35}$

In addition to the inclusion of Chagas' work on the agenda of European tropical medicine (involved in elucidating the complex relationship between pathogens, vectors and humans), the meanings attributed to the discovery of the new trypanosomiasis as a 'great achievement' of Brazilian science were associated with the special importance that the episode assumed in the socio-historical context of Republican modernization. In this context, the problems and directions of Brazil were being discussed exhaustively, particularly the role of science in this process (Alonso, 2002; Sá, 2006).

A key aspect to understanding the significance given to the discovery by Carlos Chagas was its importance for the legitimation and scientific and political visibility of the institutional model of science that was proposed by Oswaldo Cruz (Stepan, 1976; Schwartzman, 1979; Benchimol, Teixeira, 1993; Britto, 1995). The discovery in Lassance was decisive in broadening 
the scope of Manguinhos beyond the strict and pragmatic goals that had motivated its creation, enabling it to become a renowned center for the production of immunobiological preparations, and also for teaching and research, in line with the model of the Institut Pasteur in Paris. As was pointed out by Nancy Stepan (1976), the discovery and study of American trypanosomiasis were very important for an institution that sought public legitimation as an institute of 'applied' science attuned to the specific demands of society (through the production of vaccines, implementation of health campaigns, etc.) and, at the same time, a research center active in expanding the frontiers of science in line with the international agenda.

Chagas' works gave new meaning to the concept of the social appropriation of science. ${ }^{36}$ The knowledge produced in Instituto Oswaldo Cruz came to be seen as being of interest to Brazilian society, not only for providing immediate answers to problems that were on the current agenda, but also for its ability to identify new problems to be tackled. In other words, the researchers not only complied with demands, but also 'created' them by presenting themselves as being capable of providing solutions for such demands. This is the concept of the social utility of science which arises not only from the materialization of knowledge into products and actions, but also from the close link between science and national project. The scientists themselves - by adopting the profile of an intelligentsia (Mannheim, 1974) - set themselves up as the spokespersons of society; thus, the issues they raised assumed public relevance.

The discovery of Chagas disease was hailed and continues to be acclaimed by contemporaries and by medical historians as the 'crowning glory' of Brazilian science. One of the recurrent themes has been the idea that it was a 'unique achievement' in the history of medicine because the same researcher discovered a new vector, a new parasite and a new disease in quick succession. Oswaldo Cruz himself, who made every effort to publicize the work of his illustrious disciple both in the country and abroad, stressed this fact. In a lecture presented at the Biblioteca Nacional (1915, p.353), he said:

\footnotetext{
Among the protozoan diseases that we treat, the one that stands out most among them all from our standpoint - namely diseases that were studied in Brazil - is undoubtedly American trypanosomiasis, quite appropriately known as 'Carlos Chagas disease' in just tribute to its discoverer. ... Never, until now, in the field of etiological research, has such a fully researched and brilliant discovery been made in such a short time and, what is more, by a single researcher. ${ }^{37}$
}

The idea of an 'unprecedented' feat was also stressed in the speech that Miguel Pereira made as incumbent president of the Academia Nacional de Medicina, when he welcomed Carlos Chagas as a full member in 1910: "Dr. Carlos Chagas, your admission to our ranks is in a manner unparalleled in the history of this academy. In view of the exceptional and unprecedented standing that you have acquired in the field of Brazilian medicine, the Academy has quite rightly, and with full justification, decided that your admission to the group of full members be given the notoriety and prominence of an exception to the rule" (ANM, Oct 27 1910, p.3). ${ }^{38}$

For the first time in its history, the Academy admitted a new member without a seat becoming vacant. At that ceremony electrical lighting was used for the first time in the 
Academy premises and gave powerful symbolic significance to the tribute, invoking the sense of 'modernity' that was to be enshrined in a space that was also particularly evocative of the 'new age' that lay ahead. In the main auditorium of the Silogeu Brasileiro building, in the heart of the newly renovated city, this was more of a major tribute to Brazilian science per se as being an instrument for the 'civilization' of the country.

François Delaporte $(1995,2003)$ queries this 'mythology' and argues that what everybody considered to be "the most beautiful example of the power of logic in the service of science" (Cruz, 1915, p.354) was, in fact, an unexpected development in a research hypothesis originally unrelated to the idea of a human disease, as Chagas believed that the flagellate detected in the 'barbeiro' bug could be a stage of T. minasense. Analyzing Chagas' reports, the author points out that from a given moment onwards, due to the criticisms regarding some of his pronouncements ${ }^{39}$, the former altered the order and significance of the events, declaring that even before finding the 'barbeiro' bug he suspected the existence of a disease unknown in the region; as soon as he dissected the insect, he thought he had found a parasite that was pathogenic to humans. Delaporte (1995, p.40) claims that this narrative buildup into a "Brazilian epic" is a "historically false reconstruction", seeking to transform a process that was the result of the 'deviation' of an initially flawed hypothesis into a logical chain of events.

Since the discovery, physicians and scientists have been producing narratives elevating Chagas to the status of a 'hero'. From the standpoint of historians, this 'mythification' is connected with the status and significance that the discovery and study of new disease played in the institutionalization of Brazilian medicine and science (see Stepan, 1976, 2001; Benchimol, Teixeira, 1993; Britto, 1995; Coutinho, 1999; Kropf, 2009). Dealing with this national dimension does not mean creating "nationalistic history", as suggested by Delaporte (2003, p. 327). On the contrary, it involves conducting a historical analysis, which is to place the disease in the social context that gave it its significance. Furthermore, by putting the matter in terms of 'errors' and 'false reconstruction', Delaporte ignores the fact that both the 'changes of course' and attempts to minimize them are invariably dimensions involved in the process of production and validation of scientific knowledge. Scientific activity is full of treacherous trails, abandoned assumptions, unforeseen issues, conflicts of interest and other factors, which are deliberately 'erased' at the end of the process by the scientists as if things had progressed 'naturally' toward the 'truth'. Not only these procedures, but also the creation of myths and 'epics' are common and constitute part of science (and any other social activity). Historians are not required to 'denounce' the strategies behind the construction of myths, but they need to explain them, linking them to the specific social and historical circumstances in which they occurred. ${ }^{40}$

It was precisely as a symbol of the scientific project embodied in the IOC that the discovery of Chagas disease assumed the importance it did and had repercussions as a 'unique achievement' in Brazilian science, and this naturally had an influence on the significance attributed to the object that it 'revealed'. As it was made possible in the context of the cognitive resources of tropical medicine and with the political and institutional resources available at Manguinhos, the disease described from 1909 onwards would become not only a 'new disease,' and a scientific fact, but also a social fact and a 
'framework' for a fresh look at the nation and its problems, and at the social role of science in solving them. ${ }^{41}$

Chagas (1910b) presented the first clinical characterization of the disease that would come to be named after him in 1910 at the Academia Nacional de Medicina. The acute phase was divided into two forms: cases with severe brain disorders (usually children less than one year of age that hardly ever survived), and cases - far more frequent - without those symptoms that rapidly progressed to the chronic stage. According to him, the chronic phase included neurological, cardiological and especially endocrinological disorders, particularly thyroid complications. Hence the name 'parasitic thyroiditis', proposed by physician Miguel Pereira in 1910 and widely used in Chagas' early works. For him the most characteristic clinical symptom of the disease was hypertrophy of the thyroid (goiter), which was the 'stamp of the disease', in the words of Miguel Couto. ${ }^{42}$

Well-known since ancient times, the endemic goiter was very common in the state of Minas Gerais (and other regions in the interior of the country), and was considered by naturalists, travelers and physicians since the eighteenth century to be one of the main reasons for the 'backwardness' of the peasants in that state (Marques, Mittre, 2004). ${ }^{43}$ At the beginning of the twentieth century, several authors based on the microbial theory put forward the idea that endocrine diseases were infectious (Delaporte, 2003). Chagas claimed that in places where there was trypanosomiasis, the endemic goiter was not the same as in Europe (which many already attributed to a lack of iodine). He believed it was caused by the action of Trypanosoma cruzi on the thyroid. In addition to the 'neck swelling', the disturbances of motricity, language and intelligence arising from the 'nervous form' of the trypanosomiasis assumed great importance in the characterization that Chagas made of the medical and social importance of the disease, as an important factor of 'degeneration' in the rural areas of the country.

The profile of the new trypanosomiasis revealed a medical/scientific entity and also a social issue. In his conference at the Academia Nacional de Medicina, Chagas (1910b, p.446) declared that Brazil was facing a "terrible scourge over a large area of the country, making a considerable number of people incapable of physical activity, creating successive generations of debilitated humans and useless individuals inevitably doomed to a chronically diseased condition to such an extent that it renders them unable to participate in the progressive evolution of the country". ${ }^{44}$ His words were emphasized using resources with highly persuasive results. Electric lighting inaugurated at the same occasion, as a symbol of the Belle Époque prevailing in the recently refurbished capital, was used by Chagas to project footage filmed in Lassance showing patients (mostly children with neurological disorders) and 'barbeiro' bugs that infested the wattle and daub homes of the region, projecting disturbing images of Brazilians - who were seen as the antithesis of 'civilization' - in the center of medicine and capital of the country. The laboratory apparatus was also on display to convince the audience. In addition to anatomical and pathological equipment, 16 microscopes were available for those who wished to see the new parasite (ANM, Oct 27 1910). The 'spectacle' was widely covered in the press. In $O$ País, the military physician Ismael da Rocha (1910, p.6) declared: "Brazil witnesses a step forward for mankind and a step backward in the brutal reality, which the authorities need to address without delay". ${ }^{45}$ 
The pronouncements of Chagas had major repercussions. In the Câmara Federal, Camillo Prates, deputy for the State of Minas Gerais, called for immediate action by the federal authorities. The Correio da Manhã newspaper applauded the initiative and stated: "Brazil is not Rio de Janeiro alone. Our legislators and politicians should not forget that a million Brazilians live here in relative comfort, while in the sertões (backlands) there are about eighteen million struggling hard to survive" (Vidal, 18 Nov. 1910, p.1; emphasis added). ${ }^{46}$

In his speeches in the main medical associations around the country, Chagas continued his denunciations demanding drastic measures to confront the sanitary and social 'calamity' caused by this and other endemic diseases in rural areas. With the intense nationalistic debate promoted at the time of the First World War, the process of medical and social 'framing' of Chagas disease increased in intensity during the so-called sanitation movement (1916-1920), the most memorable declaration being that of physician Miguel Pereira in 1916 stating that Brazil was one 'enormous hospital'. ${ }^{47}$

Brought to the public's attention by the nationalistic debate, Chagas disease then came under criticism. In 1919, some doctors questioned its clinical definition and social importance. Denying the association with goiter, they argued that cases of the disease did not exceed fifty individuals, in contrast with the 'three millions' bandied about by leaders of the sanitation movement (Penna, 1918, p.96-145). The scientific dimension could not be dissociated from the social and political dimension assumed by the 'disease of Brazil' (Kropf, 2009). Chagas' critics said that the idea of a 'diseased country' was exaggerated and pessimistic and would discredit Brazil abroad. The controversy further intensified in 1922/1923 at the Academia Nacional de Medicina, when doubts were also cast regarding authorship of the discovery of Trypanosoma cruzi: according to some, it should have been attributed to Oswaldo Cruz, for he had been the person who conducted the experimental infection that revealed the new parasite. The findings of the Academy reiterated Chagas' merit and full responsibility for the discovery, though it failed to address the question of the geographical distribution of the disease.

The controversy created a mood of uncertainty about the disease. It is widely believed that for this reason Chagas was not awarded the Nobel Prize, for which he was nominated for the second time in 1921 (Coutinho, Freire Jr., Dias, 1999). Nevertheless, he continued his research until his death in 1934. In the IOC, Chagas' disciples then proceeded to foment new interest in the disease, especially involving clinics in the hinterlands, and produced new cognitive and social agreements such that the disease that had become the symbol for the abandonment of the Brazilian backlands (sertões) was finally recognized during the 1940s as a scientific fact and a national public health problem (Kropf, Azevedo, Ferreira, 2003; Kropf, 2009). The correlation with the endemic goiter was abandoned and the disease came to be characterized as a chronic cardiopathy; in 1950, the first prophylactic campaign was inaugurated with the application of insecticides in homes.

\section{Final considerations}

Being seen as the 'backlands disease' or 'endemic rural scourge', Chagas disease imposed specific contours on the concept of 'tropical disease'. It was represented as the 'disease of 
Brazil' in several senses, not merely in the geographical sense. It was the attribute of a 'diseased country', which could not achieve 'civilization' on account of endemic diseases that jeopardized the vitality of its workers, and at the same time, the symbol of science that 'revealed' this unknown Brazil and showed the way forward for its incorporation to the national march towards 'progress'.

In his speeches, Chagas himself used to emphasize the national significance of tropical medicine in Brazil. In the inaugural lecture he gave as professor of tropical medicine at FMRJ in 1926, he stressed that the discipline created by Patrick Manson in 1899 in England should be established in Brazilian medical teaching not only for issues strictly related to the advancement of scientific knowledge, but also because tropical diseases - especially the endemic rural diseases such as Chagas disease, malaria and ankylostomiasis - were "the most pressing of our medical and social problems" (Chagas, 1935, p.138).

David Arnold (1996) contends that one of the main features of 'medicine of warm climates', even before it formally became incorporated in Mansonian tropical medicine, was the sense of 'otherness' that the tropics - understood not merely in their physical/ geographical dimension but as a conceptual space, by associating cultural, political and aesthetic elements - signified from the European perspective. This dimension of 'tropicality' (Arnold, 1996; Stepan, 2001), understood in the concrete historical and social circumstances that give it significance in different contexts, acquired unique historical significance in Brazil as well. If, for Manson, the justification for the specific study of tropical diseases was the fact that they were the diseases that Europeans faced in the colonies (Manson, 1897), this political and social dimension of tropical diseases was similarly a factor coupled to scientific interest and investment on the subject in Brazil.

In Chagas' words (Chagas, 1935, p.138), "the destinies of our nation, its greatness and the happiness of its people cannot forego the benefits of your professional services, that must extend throughout this vast and boundless territory, in order to populate it and enrich it. Be mindful of patriotism in this task and study the disease of Brazil assiduously" ${ }^{48}$

According to Chagas, American trypanosomiasis was "an essentially Brazilian disease," both "for the overriding reason of having been recorded here and the fact that the major epidemiological, ethiopathogenic and clinical aspects were all discovered here", and also by virtue of representing a "disease that, above all others, epitomizes Brazilian pathology" (Chagas, 1935, p.163). At the same that Chagas disease allowed the presentation of the country as evidence in a dialogue within international medical scientific circles, it enabled Brazil itself to 'encounter' an 'other' Brazil which, though 'distant' and 'different', had to be seen as representative of its nationality. As with Euclides da Cunha (1902), science at Instituto Oswaldo Cruz, 'speaking' to the world, revealed the backlands dwellers (sertanejos) as Brazilians 'exiled in their own country'.

\section{NOTES}

${ }^{1}$ Research for this article was funded by the Programa Estratégico de Apoio à Pesquisa em Saúde (Strategic Program for Support of Health Research)/Fundação Oswaldo Cruz (Oswaldo Cruz Foundation) and by the Conselho Nacional de Desenvolvimento Científico e Tecnológico (CNPq; National Council of Scientific 
and Technological Development). We would like to thank Jaime Benchimol for his suggestions and commentaries on the initial draft of the text.

${ }^{2}$ About the history of the Instituto Oswaldo Cruz, also known as Instituto de Manguinhos (Manguinhos Institute), see Stepan, 1976; Benchimol, 1990; and Benchimol, Teixeira, 1993.

${ }^{3}$ British physician Patrick Manson (1844-1922) was renowned for his research into the life cycle of the parasite that causes filariasis and for establishing in 1879 that mosquitoes play a crucial role in transmission of the disease to humans, serving as an 'intermediary host' for the parasite, whereby, the latter spend part of its life cycle in the body of the insect before transferring to the 'definitive host', namely human beings. In direct conjunction with the expansion of Imperialist, especially British, interests the argument that tropical diseases required specific knowledge for their diagnosis, prophylaxis and treatment, particularly as a means of assisting the work of European doctors in the colonies, was put forward by Manson (who was adviser to the Colonial Office), in October 1897, in a conference addressed to students at Saint George's Hospital in London (Manson, 1897). In 1898, Manson released the first edition of his Tropical diseases: A manual of the diseases of warm climates (Manson, 1903). In 1899, the first schools of tropical medicine were set up in Liverpool and London, followed by the founding of similar institutions in other countries (Worboys, 1997).

${ }^{4}$ Chagas had already been appointed by Oswaldo Cruz - who was both in charge of Instituto de Manguinhos as well as being head of Diretoria Geral de Saúde Pública (DGSP; General Directorate of Public Health) - to combat two outbreaks of the disease: the first in 1905 in Itatinga, São Paulo, where the Companhia Docas de Santos (Santos Docklands Company) was building a hydroelectric plant to supply power to the port, and the second in 1907 in Xerém in the Baixada Fluminense, where the Inspetoria Geral de Obras Públicas (General Office of Public Works) performed water catchment works for the federal capital. On prophylactic campaigns for malaria and the modernization works undertaken in Brazil in the first decades of the twentieth century, see Benchimol, Silva, 2008. For biographical data on Carlos Chagas, see Chagas Filho, 1993 and Kropf, Hochman, 2007.

${ }^{5}$ In 1904, a railroad station was inaugurated in Curvelo and two years later, a station was opened in Corinto. In the summer of 1906/1907, malaria paralyzed work on the bridge over the Bicudo river delaying construction of the branch line to Pirapora. The station in Lassance was inaugurated in February 1908 and Pirapora station was opened in 1910. The project to extend the railroad to the northern state of Pará did not materialize (ANPF, 2005).

${ }^{6}$ African animal trypanosomiasis or nagana disease is caused by Trypanosoma congolense, Trypanosoma vivax and Trypanosoma brucei spp. Surra is caused by Trypanosoma evansi, mainly affecting horses and camels.

${ }^{7}$ From 1901 onwards, the disease known as sleeping sickness or African lethargy spread throughout central and east Africa in a major epidemic, forcing European countries that had colonies in the region to send committees to study the topic and propose control measures. According to Worboys (1997), this was an important case for testing the precepts of the new specialty of tropical medicine. Corroborating the model of vector-borne parasites, David Bruce showed in 1903 that it was a disease caused by a trypanosome (Trypanosoma gambiense and Trypanosoma rhodesiense) and transmitted by the tsetse fly. On the history of African trypanosomiasis, see Lyons, 1992.

${ }^{8}$ In March 1908, Chagas was formally hired by the Instituto de Manguinhos, and was appointed assistant researcher.

${ }^{9}$ A free translation is provided in this article of the quoted titles and others that appear in different languages. Originally in Portuguese: "Leváramos, como ideia diretriz, a noção de constituírem os domicílios humanos o habitat predileto, senão exclusivo, do hematófago, assim como o fato, amplamente verificado, de ser o sangue humano a alimentação por excelência dele. Seria razoável pensar, daí, numa condição infectuosa intra-domiciliária e que o vertebrado hospedeiro do parasito fosse algum animal doméstico ou o próprio homem".

${ }^{10}$ Originally in Portuguese: "Num doente febricitante, profundamente anemiado e com edemas, com plêiades ganglionares engurgitadas, encontramos tripanossomas, cuja morfologia é idêntica à do Trypanosoma cruzi. Na ausência de qualquer outra etiologia para os sintomas mórbidos observados e ainda de acordo com a experimentação anterior em animais, julgamos tratar-se de uma tripanossomíase humana, moléstia ocasionada pelo Trypanosoma cruzi, cujo transmissor é o Conorhinus sanguissuga (?)". Question mark included by the author, who at that moment was in doubt about the species to which the 'barbeiro' belonged. 
${ }^{11}$ For a more detailed description of the case of Berenice, see Chagas, 1909d, p.165-166. Having recovered from severe manifestations of the acute disease she had in 1909, from 1961 onwards Berenice was monitored by researchers from the state of Minas Gerais and was subjected to various clinical and laboratory examinations. She led a normal life and had clinical manifestations compatible with those of people of her age, despite the presence of T. cruzi. At that time, samples of the parasite from the blood of the patient were isolated and kept in the laboratory with the label 'Berenice strain' and were used in various studies. When speaking to doctors and scientists, Berenice said that although she barely remembered Chagas she had kept the gifts he had given her including a medal and a doll. She also mentioned that he had proposed taking her to be educated in Rio de Janeiro, but her parents had been opposed to the idea. Berenice died of heart failure in 1981 at seventy-three years of age (Salgado, 1980).

12 The first nomination for the Nobel prize was made by the physician and researcher Manuel Augusto Pirajá da Silva from the state of Bahia. In 1908, he published a paper identifying Schistosoma mansoni (the etiological agent of intestinal schistosomiasis) in Brazil. For further details on this and the second nomination of Chagas for the Nobel Prize (in the year 1921), see Coutinho, Freire Jr., Dias, 1999.

${ }^{13}$ Created on Pasteurian lines, the IOC expanded to become a center for experimental medicine specializing in the study of tropical diseases. Its trajectory exemplifies the issues concerning the relationship between microbiology and tropical medicine, which have received considerable attention in recent historiography (Farley, 1992; Worboys, 1996). While in England the establishment of Mansonian tropical medicine represented a differentiation with respect to the institutional spaces for microbiology, according to Caponi (2002) the reconciliation between these areas/disciplines was a feature of the Brazilian experience, especially at IOC.

${ }^{14}$ Fritz Schaudinn (1871-1906) was an authority in medical science for his studies on the development of plasmodia in the digestive tract of anophelines and in human blood and, especially, for having discovered in 1905, together with Hoffmann, the cause of syphilis (Treponema pallidum) (Benchimol, Sá, 2005).

${ }^{15}$ Created in 1909, the journal of the Instituto Oswaldo Cruz published all articles in Portuguese and German prior to the First World War.

${ }^{16}$ Livros de Assentamento, Casa de Oswaldo Cruz Archives, Rio de Janeiro.

${ }^{17}$ On the creation of institutes of tropical medicine in England, see Worboys, 1988.

${ }^{18}$ The work of these two German scientists is studied in depth by Delaporte, 2003.

${ }^{19}$ Lutz initiated studies on trypanosomes, and on trypanosomiasis as an epizootic disease, in 1907. Commissioned by the Government of the State of Pará to study a disease afflicting horses on the Island of Marajó in the Amazon region, Lutz confirmed that the disease was the same as that described by Elmassien in Paraguay in 1901. The disease was locally known as 'mal-de-cadeiras'. Caused by a Trypanosoma, it is transmitted by a tabanid fly, having as its natural reservoir the capybara (Hydrochaeris hydrochaeris), a large and very common rodent in South America.

${ }^{20}$ Following the accumulation of knowledge regarding human trypanosomiasis in Africa, the Brazilian physician João Batista de Lacerda linked the cause of beriberi (a vitamin deficiency disease) to a trypanosome. In his work, published in 1907, he describes the trypanosomes he found in the spinal medulla of patients he examined or autopsied, calling it Trypanosoma beriberi (Lacerda, 1907, p.28-29).

${ }^{21}$ With respect to the trajectory of Adolpho Lutz, see Benchimol, Sá, 2005, 2006.

22 BRMN, Adolpho Lutz Fund, File 213. Museu Nacional Archives, Rio de Janeiro.

${ }^{23}$ The monkey was being exhibited at the Hagenbeck circus in Hamburg. During the first decade of the twentieth century it was customary in Europe to import exotic animals, including primates, to exhibit in circuses and zoos (Deane, 1992; Oliveira, Deane, 1995).

${ }^{24}$ In this work a new Plasmodium (P. brasilium) found in the South American 'cacajao' monkey was also described and named. It was the first description of a simian plasmodium from the New World (see Deane, 1992; Oliveira, Deane, 1995).

${ }^{25}$ Chagas initially suspected that the new parasite form found in the bugs was an intermediary stage of T. minasense.

${ }^{26}$ Originally in German.

${ }^{27}$ Giemsa had already gone back to Germany at the beginning of December. Before returning to Germany Prowazek travelled on a field trip to the state of Mato Grosso in the interior of Brazil, for a month, with Arthur Neiva, José Gomes de Faria and Fernando Soledade. Ofício n.2, 2 jan. 1909. Livros de Assentamento, Casa de Oswaldo Cruz Archives, Rio de Janeiro. 
${ }^{28}$ Prowazek $(1909$, p.308) also commented on the stage of development of flagellates, using the latest Chagas description to defend the standpoint of Ziemann, Schaudinn and Keysselitz, Minchin, Koch, Kleine, Flu and others: "The formation of some sort of cyst also seems to occur in the intermediary host (Conorrhinus). In the coelom, typical flagellate forms appear".

${ }^{29}$ For further information on Kleine's work see: http://www.itg.be/itg/DistanceLearning/LectureNotes VandenEndenE/Teksten/sylabus/03_African_trypanosomiasis.doc.

${ }^{30}$ Hartmann arrived in Manguinhos on May 10 1909, soon after Chagas' findings in Lassance. He had a contract with Instituto Oswaldo Cruz to conduct research and supervise some assistants. Chagas was one of these assistants. The strong influence Hartmann had on Chagas during subsequent research at Manguinhos is unquestionable and may be inferred by reading his published works. Indeed, Hartman co-authored some papers with Chagas on free-living protozoans and on the structure of different groups of Protozoa. Hartmann returned to Hamburg on November 17 of the same year. Livros de Assentamento, p.28. Casa de Oswaldo Cruz Archives, Rio de Janeiro.

${ }^{31}$ This is the process by which a cell is divided in two, by mitosis, and generates two genetically identical cells.

${ }^{32}$ For a detailed analysis of these comments - and the criticism that they elicited - see Delaporte, 2003, p.52-59.

${ }^{33}$ This debate had preceded the discoveries concerning the transmission of malaria, and subsequently yellow fever at the end of the nineteenth century. In this respect, see Delaporte, 2003, Benchimol, 1999 and Worboys, 1997.

${ }^{34}$ Originally in Portuguese: "Fica, destarte, excluído o papel mecânico exclusivo do hemíptero [inseto], e mesmo que esse possa atuar como simples veiculador na transmissão imediata do parasito, o que nunca verificamos, a função principal será de hospedeiro intermediário, no qual o flagelado passa por ciclo evolutivo ...".

${ }^{35}$ As stressed by Barry Barnes (1986), referring to the concepts of Kuhn, a scientific discovery is something that is explained by culture and not by nature, since nature does not 'speak' for itself, but through concepts and beliefs shared by a given community.

${ }^{36}$ On the idea of the 'social appropriation' of science, see Thomas, Kreimer, 2002.

37 Originally in Portuguese: "Dentre as doenças de protozoários de que tratamos, a que entre todas apresenta maior importância, no ponto de vista em que nos colocamos - moléstias cujo estudo foi feito no Brasil - é indubitavelmente a Tripanossomíase americana, muito merecidamente denominada 'moléstia de Carlos Chagas', como justa homenagem prestada a seu descobridor. ... Nunca, até agora, nos domínios das pesquisas etiológicas, se tinha feito descoberta tão completa e tão brilhante em tão curto prazo, e, o que é mais, por um só experimentador".

${ }^{38}$ Originally in Portuguese: "Sr. Dr. Carlos Chagas, V. Ex. entra nesta casa como ninguém nela penetrou ainda. A Academia, considerando singular e ímpar a posição que V. Ex. conquistou na medicina brasileira, decidiu e decidiu bem que a admissão de V. Ex. entre os seus titulares tivesse a notoriedade e o relevo de uma exceção".

39 About the controversy surrounding Chagas disease, which began in Argentina in 1915/1916 and gained ground in Brazil between 1919 and 1923 at the Academia Nacional de Medicina, see Benchimol, Teixeira, 1993; Coutinho, 1999; Stepan, 2001; Kropf, Azevedo, Ferreira, 2003; Delaporte, 2003 and Kropf, 2009.

${ }^{40}$ On the production of myths in science see, for example, Britto, 1995.

${ }^{41}$ Reference is made here to the formulations of the U.S. medical historian, Charles Rosenberg (1992), for whom diseases are historical and social objects framed by certain social and cognitive procedures that define them as 'specific entities', while at the same time presenting themselves as a frame for society, giving it impact, values and meaning. From this standpoint, Chagas disease is a fertile topic for reflecting on the socio-cognitive nature of the production of scientific knowledge, in line with the contemporary approaches of history and the sociology of science.

42 Delaporte (2003, p.72) argues that the 'medical concept' established by Chagas, according to which trypanosomiasis was a predominantly endocrine disease (a concept that was later criticized and rejected), was the big "obstacle" to the formulation of the 'real' concept of American trypanosomiasis, which would only emerge from studies conducted by Cecilio Romaña in Argentina from the 1930s onwards. About the anachronism in this hypothesis, see Kropf, Azevedo, Ferreira, 2003 and Kropf, 2009. 
${ }^{43}$ In the late nineteenth century, this issue achieved great public visibility in the debates on the construction of the new capital of Minas Gerais. Its presence in Curral del Rei (future Belo Horizonte) was one of the arguments for criticizing the choice of this location, known as 'arraial dos papudos' ('goiter settlement'), for the state capital to be designed in line with modern engineering and hygienic standards. Besides the lack of iodine in the water, there was much speculation about other causes, generally associated with poverty and women: poor nutrition and inadequate shelter conditions, unhygienic habits, a consequence of child delivery or hereditary defects (Marques, Mitre, 2004).

${ }^{44}$ Originally in Portuguese: “...terrível flagelo de vasta zona do país, aí inutilizando numerosa população para a atividade vital, criando gerações sucessivas de homens inferiores, de indivíduos inúteis, fatalmente votados à condição mórbida crônica, a tal coeficiente de inferioridade que os torna elementos inaproveitáveis na evolução progressista da Pátria".

${ }^{45}$ Originally in Portuguese: "O Brasil registra: no homem mais uma glória; no fato mais uma desgraça, a que os poderes públicos precisam acudir sem detença". On the impact of this first conference by Chagas, see also ANM, 27 Oct. 1910.

${ }^{46}$ Originally in Portuguese: “O Brasil não é só o Rio de Janeiro. Não esqueçam os nossos legisladores e governantes de que vive aqui, mais ou menos comodamente, um milhão de brasileiros, ao passo que mourejam nos sertões cerca de dezoito milhões".

47 About the sanitation movement, see Labra, 1985, Castro-Santos, 1985, 1987 and Lima, Hochman, 1996. Bringing together physicians, scientists, intellectuals and politicians, this campaign pointed to the precarious health conditions as being the main obstacle to the country becoming 'civilized' and effectively becoming a nation. As a political movement, it expressed itself predominantly in the claims that the Brazilian state should increase its power of intervention in the area of public health, especially in the interior of the country. With great repercussion in the press, in intellectual circles an in the Brazilian Congress, the movement, formally organized in the Liga Pró-Saneamento do Brasil (Pro-Sanitation League of Brazil), founded in 1918, led to a comprehensive reform of health services, with the creation in the early 1920s of the Departamento Nacional de Saúde Pública (DNSP; National Department of Public Health), of which Chagas was the first director. About the close link between the discovery and study of Chagas disease and the sanitation movement, see the article by Kropf, in this volume.

${ }^{48}$ Originally in Portuguese: "os destinos de nossa Terra, a sua grandeza e a felicidade de sua gente, não prescindem dos benefícios de vossa ação profissional, que se vai exercitar nesse vasto território sem limites, para povoá-lo e enriquecê-lo. Atentai bem nessa missão de patriotismo e estudai com esforço a doença do Brasil".

\section{BIBLIOGRAPHY}

ANM.

Academia Nacional de Medicina. Jornal do Commercio, Rio de Janeiro, p.3. Oct. 27910.

ALONSO, Ângela

Idéias em movimento: a geração 1870 na crise do Brasil-Império. São Paulo: Paz e Terra. 2002.

ANPF.

Associação Nacional de Preservação Ferroviária. Histórico da Estrada de Ferro Central do Brasil. Disponível em: http://www.anpf.com.br/ historico_efcb.htm. Accessed on: 16 Nov. 2005.

ARNOLD, David (Ed.).

Warm climates and western medicine: the emergence of Tropical Medicine, 1500-1900. Amsterdam/Atlanta: Rodopi, 1996

BARNES, Barry.

T. S. Kuhn y las ciencias sociales. México: Fondo de Cultura Económica. 1986.

BENCHIMOL, Jaime Larry.

Dos micróbios aos mosquitos: febre amarela e a revolução pasteuriana no Brasil. Rio de Janeiro: Editora Fiocruz, Editora UFRJ, 1999.

BENCHIMOL, Jaime Larry (Coord.). Manguinhos, do sonho à vida. A ciência na Belle Époque. Rio de Janeiro: Casa de Oswaldo Cruz, 1990.

BENCHIMOL, Jaime Larry; SÁ, Magali Romero. Adolpho Lutz e a entomologia médica no Brasil (apresentação histórica). Rio de Janeiro: Editora Fiocruz. (Adolpho Lutz Obra Completa, v.2, livro 3). 2006.

BENCHIMOL, Jaime Larry; SÁ, Magali Romero. Insetos, humanos e doenças: Adolpho Lutz e a medicina tropical. In: Benchimol, Jaime Larry; Sá, Magali Romero (Ed.). Febre amarela, malária e protozoologia. Rio de Janeiro: Editora Fiocruz. (Adolpho Lutz Obra Completa, v.2, livro 1). p.43-244. 2005.

BENCHIMOL, Jaime Larry; SILVA, André Felipe Candido da. 
Ferrovias, doenças e medicina tropical no Brasil da Primeira República. História, Ciências, Saúde - Manguinhos, Rio de Janeiro, v.15, n.3, p.719-762. 2008 .

BENCHIMOL, Jaime Larry; TEIXEIRA, Luiz Antonio.

Cobras, lagartos \& outros bichos: uma história comparada dos institutos Oswaldo Cruz e Butantan. Rio de Janeiro: Editora UFRJ. 1993.

BERENBERG-GOSSLER, H. von.

Über ein neues Trypanosom im Blute eines südamerikanischen Affen (Okanaria calwa). Archiv für Schiffs- und Tropen-Hygiene, Leipzig, bd.12, n.6, p.552. 1908.

BRANNIGAN, Augustine.

A base social das descobertas científicas. Rio de Janeiro: Zahar. 1984.

BRITTO, Nara.

Oswaldo Cruz: a construção de um mito na ciência brasileira. Rio de Janeiro: Editora Fiocruz. 1995.

BUSVINE, James R.

Disease transmission by insects: its discovery and 90 years of effort to prevent it. Berlin: Spring. 1993.

CAPONI, Sandra.

Trópicos, micróbios y vectores. História, Ciências, Saúde - Manguinhos, Rio de Janeiro, v.9, supl., p.111-38, 2002.

CASTRO-SANTOS, Luiz Antonio de. Power, ideology and public health in Brazil (18891930). Tese (Doutorado) - Harvard University, Cambridge. 1987.

CASTRO-SANTOS, Luiz Antonio de.

O pensamento sanitarista na Primeira República: uma ideologia de construção da nacionalidade. Dados. Revista de Ciências Sociais, Rio de Janeiro, v.28, n.2, p.193-210. 1985.

CHAGAS, Carlos.

Aula inaugural da cadeira de medicina tropical - 14 de setembro de 1926. In: Chagas, Carlos. Discursos e conferências. Rio de Janeiro: A Noite. p.137-166. 1935.

CHAGAS, Carlos.

Estudos hematologicos no impaludismo. Rio de Janeiro: Typografia da Papelaria União. 1903.

CHAGAS, Carlos.

Nova entidade morbida do homem.

Brazil-Medico, Rio de Janeiro, v.24, n.43-45, p.423-428, 433-437, 443-447. 1910.

CHAGAS, Carlos.

Neue Trypanosomen: Vorläufige mitteilung. Archiv für Schiffs- und Tropen-Hygiene, Leipzig, n.13, p.120-122. 1909a.
CHAGAS, Carlos.

Nouvelle espèce de trypanosomiase humaine. Bulletin de la Société de Pathologie Exotique, Paris, v.2, n.6, p.304-307. 1909b.

CHAGAS, Carlos.

Nova especie morbida do homem, produzida por um Trypanozoma (Trypanozoma cruzi): nota prévia. Brazil-Medico, Rio de Janeiro, v.23, n.16, p.161. 1909c.

CHAGAS, Carlos.

Nova tripanozomiase humana: estudos sobre a morfolojia e o ciclo evolutivo do

Schizotrypanum cruzi n. gen., n. sp., ajente etiolojico de nova entidade morbida do homem. Memórias do Instituto Oswaldo Cruz, Rio de Janeiro, v.1, n.2, p.159-218. 1909d.

CHAGAS, Carlos.

Trabalho do Instituto de Manguinhos sobre uma nova trypanosomiase humana, pelo $\mathrm{dr}$. Carlos Chagas, assistente do Instituto. Annaes da Academia de Medicina do Rio de Janeiro, Rio de Janeiro, n.75, p.188-190. 1909e.

CHAGAS, Carlos.

Uber eine neue trypanosomiasis des menschen. Archiv für Schiffs- und Tropen-Hygiene, Leipzig, n.13, p.351-353. 1909f.

CHAGAS, Carlos.

Trypanosoma minasense: nota preliminar.

Brasil Médico, Rio de Janeiro, v.22, n.48, p.471. 1908.

CHAGAS, Carlos; PROWAZEK, Stanislaus von. Bemerkung zu der Arbeit von R. Gonder und H.V. Berenberg-Gossler: Malariaplasmodien der Affen, Malaria, Bd.I, Heft 1. Malaria, Leipzig, bd.1, n.2, p.138. 1909.

CHAGAS FILHO, Carlos.

Meu pai. Rio de Janeiro: Casa de Oswaldo Cruz. 1993.

COUTINHO, Marilia.

Ninety years of Chagas disease: a sucess story at the periphery. Social Studies of Science, London, v.29, n.4, p.519-549. 1999.

COUTINHO, Marilia; FREIRE JR., Olival; DIAS, João Carlos Pinto.

The Nobel enigma: Chagas' nominations for the Nobel Prize. Memórias do Instituto Oswaldo Cruz, Rio de Janeiro, v.94, suppl. 1, p.123-129. 1999.

COUTINHO, Marilia; PINTO DIAS, João

Carlos.

A descoberta da doença de Chagas. Cadernos de Ciência \& Tecnologia, Brasília, v.16, n.2, p.11-51. 1999.

CRUZ, Oswaldo Gonçalves.

Algumas moléstias produzidas por protozoários: 
conferência feita na Biblioteca Nacional pelo dr. Oswaldo Cruz. Brazil-Medico, Rio de Janeiro, v.29, n.44, 45, p.345-346,

p.353-356. 1915.

CUNHA, Euclides da.

Os sertões. Rio de Janeiro: Laemmert. 1902.

DEANE, Leônidas

Simian malaria in Brazil. Memórias do Instituto Oswaldo Cruz, Rio de Janeiro, v.87, suppl. 3, p.1-20. 1992.

DELAPORTE, François.

A doença de Chagas: história de uma calamidade continental. Ribeirão Preto: Holos. 2003.

DELAPORTE, François.

Chagas, a lógica e a descoberta. História, Ciências, Saúde - Manguinhos, Rio de Janeiro, v.1, n.2, p. 39-53. 1995.

FARLEY, John.

Parasites and the germ theory of disease. In: Rosenberg, Charles; Golden, Janet (Ed.). Framing diseases: studies in cultural history. New Brunswick: Rutgers University Press. p.33-49. 1992.

GONDER, Richard.; BERENBERG-GOSSLER, Herbert von.

Untersuchungen über malariaplasmodien der affen. Anhang: Beschreibung von

Trypanosoma prowazeki nov. spec. (v. Gossler). Malaria. Leipzig, bd.1, n.1, p.47-56. 1908.

KLEINE, Friedrich

Weitere wissenschaftliche Beobachtungen über die Entwicklung von Trypanosomen in Glossinen. Deutsche medizinische Wochenschrift, Stuttgart, bd.35, p.924-925. 1909.

KRAUS, Otto

Laboratorium, später Abteilung fur Protozoologie. In: Mannweiler, E. Geschichte des Instituts für Schiffs- und Tropenkrankheiten in Hamburg: 1900-1945. Kelten-Weiller: Goecke \& Evers. p.152-166. 1998.

KROPF, Simone Petraglia.

Doença de Chagas, doença do Brasil: ciência, saúde e nação (1909-1962). Rio de Janeiro: Editora Fiocruz. 2009.

KROPF, Simone Petraglia; AZEVEDO, Nara; FERREIRA, Luiz Otávio.

Biomedical research and public health in Brazil: the case of Chagas disease (1909-1950). Social History of Medicine, Oxford, v.16, n.1, p.111-129. 2003.

KROPF, Simone Petraglia; HOCHMAN, Gilberto.
Chagas, Carlos Ribeiro Justiniano. In: Bynum, W.F.; Bynum, H. (Ed). Dictionary of medical biography. Westport: Greenwood Press. p.320-325. 2007.

LABRA, Maria Eliana.

O movimento sanitarista nos anos 20: da conexão sanitária internacional à especialização em saúde pública no Brasil. Dissertação (Mestrado) - Escola Brasileira de Administração Pública/ Fundação Getúlio Vargas, Rio de Janeiro1985.

LACERDA, João Baptista de. Contributions à l'étude de la cause du beribéri. Rio de Janeiro: Imprensa Nacional. 1907.

LATOUR, Bruno.

Ciência em ação: como seguir cientistas e engenheiros sociedade afora. São Paulo: Unesp. 2000.

LIMA, Nísia Trindade; HOCHMAN, Gilberto. Condenado pela raça, absolvido pela medicina: o Brasil descoberto pelo movimento sanitarista da Primeira República. In: Maio, Marcos Chor; Santos, Ricardo Ventura (Org.). Raça, ciência e sociedade. Rio de Janeiro: Fiocruz; Centro Cultural Centro do Brasil. p.23-40. 1996.

LÖWY, Ilana.

The controversy on the early history of Chagas disease. Parassitologia, Roma, v.47, n.3-4, p.329-333. 2005.

LUTZ, Adolpho.

Estudos e observações sobre o quebrabunda ou peste de cadeiras. Revista da Sociedade Scientifica de São Paulo, São Paulo, v.3, n.3-7. p.34-58. 1908.

LYONS, Maryinez.

The colonial disease: a social history if sleeping sickness in northern Zaire, 1900-1940. Cambridge: Cambridge University Press. 1992.

MANNHEIM, Karl.

O problema da 'intelligentsia': um estudo de seu papel no passado e no presente. In: Mannheim, Karl. Sociologia da cultura. São Paulo: Perspectiva. p.69-139. 1974.

MANSON, Patrick.

Tropical diseases: a manual of the diseases of warm climates. 3.ed. London. 1903.

MANSON, Patrick.

The necessity for special education in tropical medicine. Lancet, London, n.2, p.842-845. 1897.

MARQUES, Rita de Cássia; MITRE, Sérgio Munir.

Bócio endêmico em Minas Gerais: a pesquisa biomédica na terra dos 'papudos'. In:

Nascimento, Dilene R.; Carvalho, Diana M. 
(Orgs). Uma história brasileira das doenças. Brasília: Paralelo 15. p.182-93. 2004.

OLIVEIRA, Ricardo; DEANE, Leônidas. Simian malaria at two sites in the Brazilian Amazon, 1: the infection rates of Plasmodium brasilium in non-human Primates. Memórias do Instituto Oswaldo Cruz, Rio de Janeiro, v.90, n.3, p.331-339. 1995.

PENNA, Belisário.

Saneamento do Brasil. Rio de Janeiro: Tip. Revista dos Tribunais. 1918.

PERLETH, Matthias.

Historical aspects of American Tripanosomiasis (Chagas' disease). Frankfurt: Peter Lang. 1997.

PROWAZEK, Stanislas von.

Kritische Bemerkungen zum

Trypanosomenproblem. Archiv für Schiffs- und Tropen-Hygiene, Leipzig, bd.13, n.10, p.301-308. 1909.

PROWAZEK, Stanislas von.

Studien über Säugetier: Trypanosomen. Arb. K. Gesundheitsamte, bd.xxii, ss.351-195. 1905.

ROCHA, Ismael da.

A doença de Carlos Chagas: uma sessão memorável na Academia Nacional de Medicina. O Paiz, Rio de Janeiro. 31 out. 1910, p.6.

ROSENBERG, Charles.

Framing disese: illness, society and history.

In: Rosenberg, Charles; Golden, Janet (Ed.).

Framing disease: studies in cultural history.

New Brunswick: Rutgers University Press. 1992.

SÁ, Dominichi Miranda de.

A ciência como profissão: médicos, bacharéis e cientistas no Brasil (1895-1935). Rio de Janeiro: Editora Fiocruz. 2006.

SÁ, Magali Romero.

The history of tropical medicine in Brazil: the discovery of Trypanosoma cruzi by Carlos Chagas and the German school of protozoology. Parassitologia, Roma, v.47, n.3-4, p.309-317. 2005.

SALGADO, João Amílcar.

O centenário de Carlos Chagas e a menina Berenice. Memórias do Instituto Oswaldo Cruz, Rio de Janeiro, v.75, n.1-2, p.193-195. 1980.
SCOTT, Harold.

A history of tropical medicine. London: Edward Arnold. 1942.

SCHWARTZMAN, Simon. Formação da comunidade científica no Brasil. São Paulo; Rio de Janeiro: Ed. Nacional; FINEP. 1979.

STEPAN, Nancy Leys.

Picturing Tropical Nature. London: Reaktion Books. 2001.

STEPAN, Nancy Leys.

Beginnings of Brazilian Science: Oswaldo Cruz, Medical Research and Policy, 1890-1920. New York: Science History Publications. 1976.

THOMAS, Hernán; KREIMER, Pablo. La apropiabilidad social del conocimiento científico y tecnológico: una propuesta de abordaje teórico-metodológico. In: Dagnino, Renato; Thomas, Hernán (Org.). Panorama dos estudos sobre ciência, tecnologia e sociedade na América Latina. Taubaté: Cabral Editora e Livraria Universitária. p.273-288. 2002.

VIDAL, Gil.

Uma calamidade. Correio da Manhã

Rio de Janeiro, p.1. 18 nov. 1910.

WORBOYS, Michael.

Tropical diseases. In: Bynum, W.F.; Porter, Roy (Ed.). Companion encyclopedia of the history of medicine. v.1. London: Routledge. p.512-536. 1997.

WORBOYS, Michael.

Germs, malaria and the invention of mansonian tropical medicine: from 'diseases in the tropics' to 'tropical diseases'. 2.ed. In: Arnold, David (Ed.). Warm climates and western medicine: the emergence of tropical medicine, 1500-1900. Amsterdan: Rodopi. p.181-207. 1996.

WORBOYS, Michael.

Manson, Ross and colonial medical policy: tropical medicine in London and Liverpool, 1899-1914. In: McLeod, Roy; Lewis, Milton (Ed.). Disease and empire: perspectives on Western medicine and the experience of European expansion. London: Routledge. p.21-37. 1988.

\section{$\rightarrow \rightarrow \rightarrow<<<$}

